O.M. Lavrynenko, O.Yu. Pavlenko, M.N. Zahornyi, S.F. Korichev

\title{
MORPHOLOGY, PHASE AND CHEMICAL COMPOSITION OF THE NANOSTRUCTURES FORMED IN THE SYSTEMS CONTAINING LANTHANUM, CERIUM, AND SILVER
}

\author{
Frantsevych Institute for Problems of Materials Science of National Academy of Sciences of Ukraine \\ 3 Krzhyzhanovskii Str., Kyiv, 03680, Ukraine, E-mail: alena.lavrynenko@gmail.com
}

$X$-ray phase and thermogravimetric analysis, scanning electron microscopy and energy-dispersion spectroscopy were used to study the products of phase formation during the precipitation of lanthanum and cerium salts in the presence of silver nitrate and recipients of precipitators, nucleating agents and hydrolysis regulators. Thermogravimetric analysis shows the completion of the $\mathrm{La}(\mathrm{OH})_{3}$ lattice dehydroxylation process at a temperature of $\sim 300{ }^{\circ} \mathrm{C}$ and probable destruction of sulfates at a temperature of $\sim 340{ }^{\circ} \mathrm{C}$. The phase interaction of lanthanum oxide(III) with silver ends at $T \sim 400^{\circ} \mathrm{C}$. The DTG curve shows a two-stage weight loss, which characterizes the destruction of lanthanum and silver hydroxides $\left(250^{\circ} \mathrm{C}\right)$ and the removal of sulfates $\left(\sim 340^{\circ} \mathrm{C}\right)$, respectively. According to the TG, the total weight loss is $21.6 \%$. For the cerium-containing system the only endothermic effect of dehydroxylation of cerium hydroxide at $T=250{ }^{\circ} \mathrm{C}$ with its conversion into cerium dioxide is observed. The destruction of nitrates (anionic component of solutions) takes place at the temperature of $400^{\circ} \mathrm{C}$. Weight loss takes place at $T=150{ }^{\circ} \mathrm{C}$ and is $53.9 \%$. Thus, on the basis of TG-DTA data, it can be assumed that the formation of composites particles based on lanthanum and cerium oxides, modified with silver, ends at the temperature of $400{ }^{\circ} \mathrm{C}$. The X-ray diffraction data shows that at the initial stage the system undergoes the formation of cerium and lanthanum hydroxides, and during lyophilization of the precipitate $\left(T=160^{\circ} \mathrm{C}\right)$ the crystal lattice of hydroxides partial dehydroxylation takes place with the formation of trigonal oxides $\mathrm{La}_{2} \mathrm{O}_{3}$ and $\mathrm{Ce}_{2} \mathrm{O}_{3}$. It has been found that the presence of silver cations in the solution can affect the phase composition of lyophilized structures and the formation of the $\mathrm{CeO}_{2}$ phase. It is shown that the hydroxylamine chloride injection into the system can initiate the silver restoration on the lanthanum oxide surface and also partially restore it to the LaO phase. Temperature treatment of the samples $\left(T=400{ }^{\circ} \mathrm{C}\right)$ promotes homogenization of the precipitate composition: formation of $30 \mathrm{~nm}$ cerium dioxide particles with silver clusters evenly distributed on its surface, and hexagonal lanthanum oxide plates with individual silver particles as the second phase. In three-component systems, two modifications of lanthanum oxides (trigonal and cubic), cerium dioxide and metallic silver are formed. It is found that the chemical composition of the precipitates contains the main elements - La, Ce, $\mathrm{O}, \mathrm{Ag}$ and impurity $-\mathrm{S}$ or $\mathrm{Cl}$, as the anionic component of the initial solutions, $N$ and $K$ in the composition of the initial suspension. It is shown that the morphology of the samples is represented by hexagonal structures of lanthanum hydroxide and oxide, spherical and pseudocubic particles of cerium dioxide and lanthanum oxide, spherical clusters of silver.

Keywords: trigonal lanthanum oxide, cerium dioxide, doping of REE oxides with silver, phase formation, morphology of cerium and lanthanum oxides, silver

\section{INTRODUCTION}

When conducting modern medical and biological research, among the whole variety of oxides of rare earth elements (REE), systems based on cerium dioxide are most often used, for which the special term "nanoceria" has been introduced in the scientific literature [1]. Structure-sensitive properties and biomedical applications of nanodispersed cerium dioxide are shown in paper [2]. Interest in these systems is based on the capability of cerium oxide particles to absorb oxygen and reversible transition between $\mathrm{Ce}^{3+}$ and $\mathrm{Ce}^{4+}$ cations on their surface, which is used in catalytic and photocatalytic processes $[3,4]$. The use of cerium oxide nanoparticles in biology and medicine is associated, for example, with their auto-catalytic anti-oxidant behavior $[5,6]$. Nanoceria is known as free radical scavenger or antioxidant [7] that is distinguished by biocompatibility and provides a significant neuroprotective and regenerative effect that has been studied on rats [8]. Ceria nanoparticles possess unique oxidase-like activity, as they can facilitate the fast oxidation of organic dyes and small molecules under slightly acidic conditions without the need of hydrogen peroxide [9]. The key protective role 
of nanoparticles is closely connected with their possibility to absorb harmful UV radiation without scattering the useful visible one and reducing oxidative stress damage, such as that induced by $\mathrm{H}_{2} \mathrm{O}_{2}$, thanks to the surface redox $\mathrm{Ce}^{3+}-\mathrm{Ce}^{4+}$ reactivity of nanoparticles [10]. In biological research, particles of lanthanum oxide are much less widespread, which, nevertheless, exhibit hemocompatibility and antibacterial properties [11]. Lanthanum oxide is also used in the production of fluorescent materials based on hydroxyapatite, which use rare earth elements, including lanthanum $\left(\mathrm{La}^{3+}\right)$, that have been developed in the biomedical field [12] and as a tracer for the study of tight junctions in epithelia by transmission electron microscopy [13]. Numerous experimental and review works have been devoted to the biomedical application of silver, in particular, $[14,15]$, however, until now, the question of the mechanisms of its interaction in biological systems including human body [16], toxicity of nanosized silver particles [17], its bactericidal, cytotoxic [18] and therapeutic [16] action remains controversial.

Nanoscale composites based on rare earth oxides modified with various noble metals, including silver, are considered as attractive materials for technical and biomedical applications due to the combination and improvement of their individual intrinsic properties. In particular, the decoration of cerium dioxide particles with silver makes it possible to obtain materials with improved photocatalytic properties as a charge carrier and the improvement of photocatalysis performance. The decoration of $\mathrm{Ag}$ nanoparticles on $\mathrm{CeO}_{2}$ nanorods can also prevent the recombination of e--h+ pairs by efficient electron transfer from $\mathrm{CeO}_{2}$ to $\mathrm{Ag}$ [19]. Structures of composite particles $\mathrm{Ag}-\mathrm{La}_{2} \mathrm{O}_{3}$ in which silver particles are localized on the surface of lanthanum oxides, and are restored from solution using sodium borohydride as a reducing agent, showed antioxidizing and significant antibacterial effect in vitro. Thus, the obtained composites can be potentially extended to develop drug-labels and other antibacterial agents [20,21]. Silver-cerium nanoparticles, synthesized using the sol-gel method from solutions of cerium nitrate and silver, which are spherical silver particles coated with nano cerium showed higher inhibitory properties compared to uncoated bare silver particles. The disinfection effect of Ag-doped
$\mathrm{CeO} \mathrm{NP}$ was more pronounced on Staphylococcus aureus than Escherichia coli, although the difference was not wide. The catalytic effect of cerium oxide particles obtained using an inexpensive precipitation method and evaluated their disinfecting aptitudes with the turbidimetric and plate count methods was used for cytotoxicity toward microorganisms at room temperature [22]. Wherein the silver-doped ceria exhibits the highest sterilization capability, yet the undoped ceria is the most intriguing. The disinfection effect of undoped ceria is moderate in magnitude, demanding a physical contact between the ceria surface and bacteria cell wall, or the redox catalysis that can damage the cell wall and result in the cell killing. Evidently, this effect is short-range and depends strongly on dispersion of the nanoparticles. In contrast, the disinfection effects of silver-doped ceria reach out several millimeters since it releases silver ions to poison the surrounding microorganisms. It should be noted that particles of this type obtained by a facile oxidation-reduction reaction method have been characterized as electrocatalysts for the air cathode of lithium-air batteries operated in a simulated air environment. [23]. The photocatalytic properties of the novel $\mathrm{Ag}$ decorated by $\mathrm{CeO}_{2}$ catalyst that are effective under sunlight upon the textile pollutant Rose Bengal destruction are considered in the work [24]. It was found that great enhancement of the degradation efficiency for $\mathrm{Ag} / \mathrm{CeO}_{2}$ compared to pure $\mathrm{CeO}_{2}$ can be ascribed mainly due to decrease in its band gap and charge carrier recombination rate. The possible degradation mechanism has been proposed, it shows the effect of generation of oxygen vacancies owing to the decoration of $\mathrm{Ag}$ on the $\mathrm{CeO}_{2}$ surface. The role of silver clusters in enhancing the photocatalytic activity of cerium oxide particles obtained by the hydrothermal method is indicated in the article [25]. Asprepared $\mathrm{Ag} \mathrm{NC} / \mathrm{CeO}_{2} \mathrm{NPs}$ have been employed as photocatalyst to study degradation of dye Acridine red under UV light illumination. Results showed that photocatalytic activity of the $\mathrm{Ag} \mathrm{NC} / \mathrm{CeO}_{2}$ was enhanced several times compared to pure $\mathrm{CeO}_{2} \mathrm{NP}$ even with very small amount loading of $\mathrm{Ag} \mathrm{NC}(\sim 3 \%)$. The mechanistic interpretation of the increased catalytic activity of $\mathrm{Ag} \mathrm{NC} / \mathrm{CeO}_{2} \mathrm{NPs}$ was nicely corroborated by involving participation of 
reactive oxygen species. Thus, Ag NC opens a convenient path for improving photocatalytic activity of $\mathrm{CeO}_{2} \mathrm{NP}$. Catalysts of this kind are used in the carbon oxidation process [26].

Particles of composites based on lanthanum oxide doped with cerium dioxide also exhibit catalytic properties [27]. Both citrate and solvothermal methods allowed the incorporation of $\mathrm{Ce}$ into the $\mathrm{La}_{2} \mathrm{O}_{3}$ lattice as substitution ions on La creating interstitial oxygen species leading to an abundance of electrophilic oxygen species on the catalyst surface. The citrate method originated $\mathrm{O}^{-}$and $\mathrm{O}_{2}{ }^{2-}$ oxygen species, while the solvothermal method produced $\mathrm{O}^{-}$oxygen species. These results can be related to the different types of cerium ions $\left(\mathrm{Ce}^{3+}\right.$ or $\left.\mathrm{Ce}^{4+}\right)$ on the oxide surface. The catalyst prepared by the solvothermal method showed higher concentration of $\left[\mathrm{Ce}^{3+}\right]$. The $\mathrm{O}^{-}$oxygen species predominant in the $\mathrm{La}_{0.75} \mathrm{Ce}_{0.25} \mathrm{O}(\mathrm{SM})$ catalyst would be responsible for higher $\mathrm{C}_{2}$ yield (by $10.5 \%$ ) at $750{ }^{\circ} \mathrm{C}$ in the oxidative coupling of methane. Generally, it is well known that the synthesis procedure strongly effects on the structure, phase and chemical composition, morphology and physicochemical properties of nanomaterial chemical composition. The aim of the present work is studying the influence of the composition of the precursor species and synthesis procedure on the phase and chemical composition of nanostructures formed in lanthanum- and cerium-based systems doped with silver. In this case the nucleation mediate stage and primary (precursor) phase growing can be indicated as the main aspect to form homogeneous materials with controlled physicalchemical properties.

\section{OBJECTS AND METHODS OF THE RESEARCH}

Particle synthesis was performed by the method of co-precipitation in an alkaline medium from solutions of $\mathrm{LaCl}_{3}, \mathrm{La}\left(\mathrm{NO}_{3}\right)_{3}$, $\mathrm{La}_{2}\left(\mathrm{SO}_{4}\right)_{3}, \mathrm{Ce}\left(\mathrm{NO}_{3}\right)_{3}$, and $\mathrm{AgNO}_{3}$ when adding substances of nucleating agents and hydrolysis regulators to the system. To obtain particles of nanocomposites based on lanthanum and cerium oxides with dopant substances it was selected $\mathrm{Ag}^{+}$(for both oxides) and $\mathrm{Ce}^{3+}$ (for lanthanum oxide) in the mass ratio of 2 and 4 wt. \%, due to the recommended optimum of $3 \mathrm{wt} . \%$ for structures designed for photocatalytic reactions [25]. The precipitates were dried in an oven at
$T=160{ }^{\circ} \mathrm{C}$, and then calcined at $T=400{ }^{\circ} \mathrm{C}$ for $5 \mathrm{~h}$. In addition, silver was restored from $\mathrm{AgNO}_{3}$ solution to the surface of pre-synthesized particles of cerium and lanthanum oxides, and the composition and morphology of threecomponent composite structures based on lanthanum oxide modified with cerium and silver were obtained and studied at a mass content of 2 and 4 wt. $\%$.

The samples were visualized by scanning electron microscopy (SEM). Electron micrographs of the samples were recorded on a MIRA3 TESCAN scanning electron microscope. Determination of the phase composition of the obtained samples was performed by the method of powder X-ray diffraction phase analysis on the DRON-3 device with radiation of the copper anode $\left(\mathrm{Cu} K_{\alpha}\right)$. The scanning step was $0.05-0.1$ degrees, exposure $-4 \mathrm{~s}$, range of $2 \theta$ angles from 15 to $90^{\circ}$. Samples were taken at standard temperature. The International Powder Standards Committee (JSPDS International Center for Diffraction Data 1999) database was used to determine the phase composition. A simultaneous study of thermogravimetric and differential thermal properties (TG-DTA) of the composite particles were performed in the static air atmosphere by a derivatograph Q-1500D (Hungary). The parameters of the pattern recording were as follows: the samples $200 \mathrm{mg}$ were heated at the rate $10^{\circ} \mathrm{C} / \mathrm{min}$ from 20 to $1000^{\circ} \mathrm{C}$; the sensitivity was $20 \mathrm{mg}$; TG -500 , DTG - 500, and DTA - 250. The samples were placed into a corundum crucible and covered by a quartz beaker to create a homogenous temperature field.

\section{RESULTS AND DISCUSSION}

Characteristics of the primary mineral phases formed at $T=160^{\circ} \mathrm{C}$. The phase composition study of lyophilized products of coprecipitation of lanthanum and cerium salts with silver nitrate at a mass content of $\mathrm{c}\left(\mathrm{Ag}^{+}\right)$of two and four wt. percent indicates the mainly hydroxide structures formation in the sediment, respectively, $\mathrm{La}(\mathrm{OH})_{3}$ (\# 13-0084) (Fig. 1 a) and $\mathrm{Ce}(\mathrm{OH})_{3}$ (\# 19-0284) (Fig. 1 c). Note that the diffractogram of the lanthanum-containing sample contains reflexes of two phases of lanthanum oxides: $\mathrm{La}_{2} \mathrm{O}_{3}$ (\# 40-1281 / 02-0688) and $\mathrm{LaO}$ (\# 33-0716) and silver nitrate (\# 6-0363). The lyophilized precipitate formed in the cerium- 
containing system also contains oxides $\mathrm{Ce}_{2} \mathrm{O}_{3}$ (\# 44-1086) and $\mathrm{CeO}_{2}$ (\# 44-1001), as well as silver nitrate. For a system of lanthanumcontaining system containing 2 and 4 wt. \% of cerium in addition to the phase of hydroxide (\# 36-1481) and oxide (\# 22-641) of lanthanum, $\mathrm{CeO}_{2}$ reflexes (\# 34-0394) are observed.
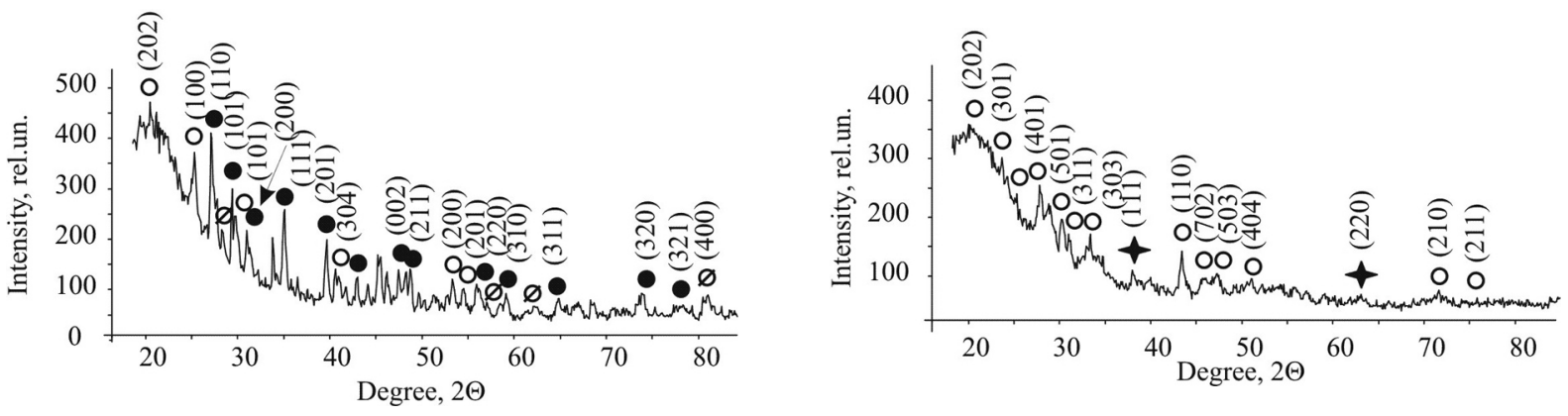

$a$

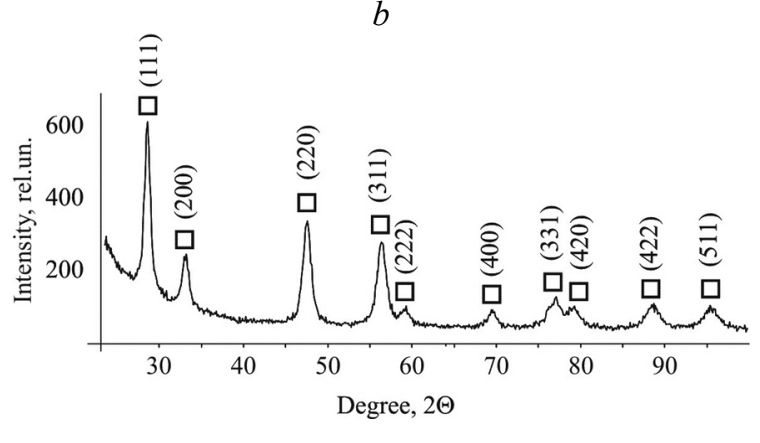

$c$
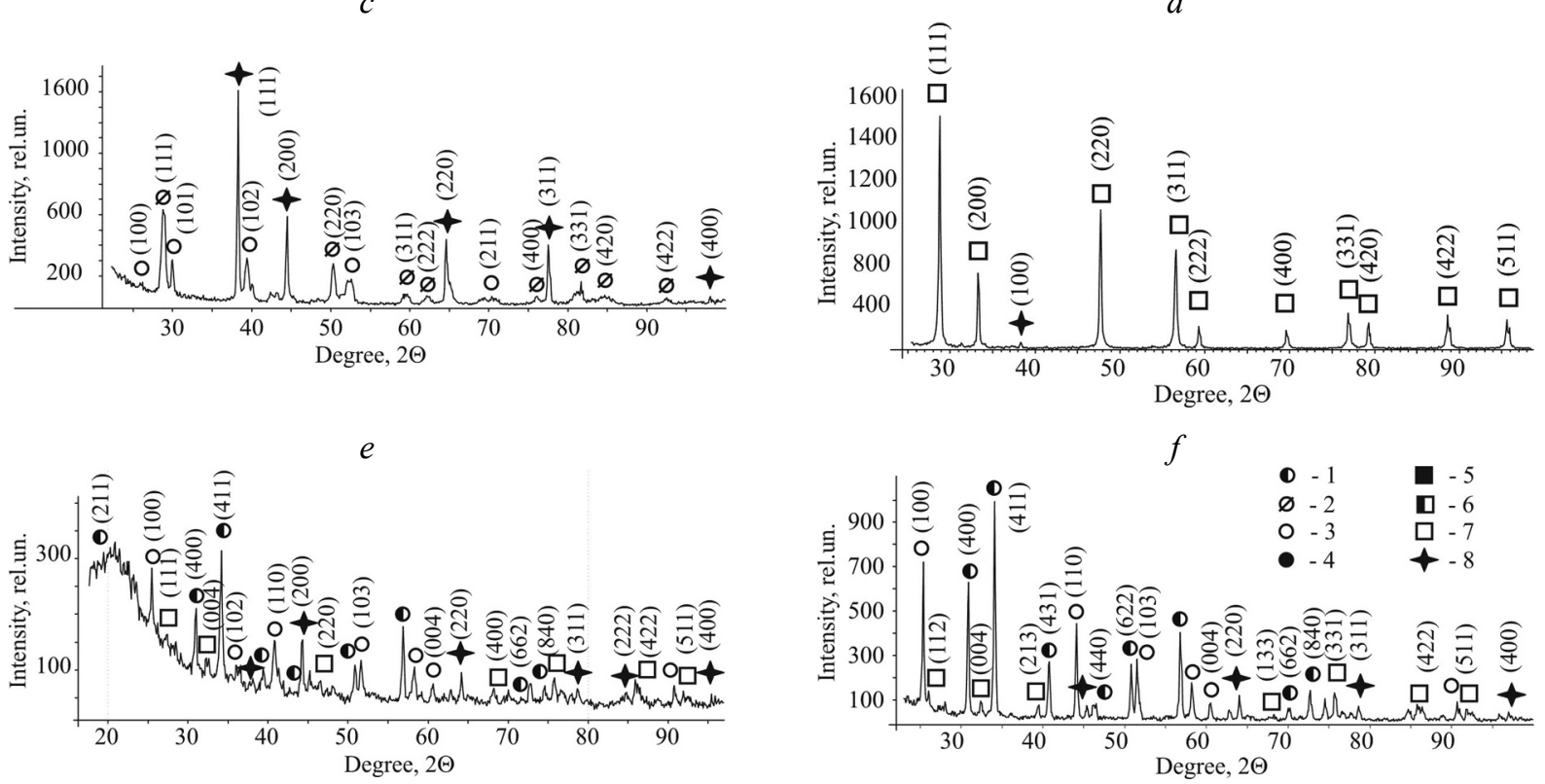

$g$

$h$

Fig. 1. XRD patterns of the samples formed in the systems: $a-\mathrm{La}_{2}\left(\mathrm{SO}_{4}\right)_{3}-\mathrm{AgNO}_{3}\left(160{ }^{\circ} \mathrm{C}\right), b-\mathrm{La}_{2}\left(\mathrm{SO}_{4}\right)_{3}-\mathrm{AgNO}_{3}$ $\left(400{ }^{\circ} \mathrm{C}, 5 \mathrm{~h}\right) ; c-\mathrm{Ce}\left(\mathrm{NO}_{3}\right)_{3}-\mathrm{AgNO}_{3}\left(160{ }^{\circ} \mathrm{C}\right), d-\mathrm{Ce}\left(\mathrm{NO}_{3}\right)_{3}-\mathrm{AgNO}_{3}\left(400{ }^{\circ} \mathrm{C}, 5 \mathrm{~h}\right) ; e-\mathrm{La}_{2}\left(\mathrm{NO}_{3}\right)_{3}-\mathrm{Ce}\left(\mathrm{NO}_{3}\right)_{3}$ $\left(160{ }^{\circ} \mathrm{C}\right) ; f-\mathrm{La}\left(\mathrm{NO}_{3}\right)_{3}-\mathrm{Ce}\left(\mathrm{NO}_{3}\right)_{3}\left(400{ }^{\circ} \mathrm{C}, 5 \mathrm{~h}\right) ; g-\mathrm{La}_{2} \mathrm{O}_{3}-\mathrm{CeO}_{2}-\mathrm{Ag} 2$ wt. \% $\left(400{ }^{\circ} \mathrm{C}, 5 \mathrm{~h}\right) ; h-\mathrm{La}_{2} \mathrm{O}_{3}-$ $\mathrm{CeO}_{2}$-Ag 4 wt. $\%\left(400{ }^{\circ} \mathrm{C}, 5 \mathrm{~h}\right)$. Numbers correspond to phases: $1-\mathrm{La}_{2} \mathrm{O}_{3}(\mathrm{P} 3 \mathrm{ml}) ; 2-\mathrm{LaO}(\mathrm{F}) ; 3-\mathrm{La}_{2} \mathrm{O}_{3}$ (la3); $4-\mathrm{La}(\mathrm{OH})_{3}(\mathrm{P} 63 / \mathrm{m}) ; 5-\mathrm{Ce}(\mathrm{OH})_{3}(\mathrm{P} 63 / \mathrm{m}) ; 6-\mathrm{Ce}_{2} \mathrm{O}_{3}(\mathrm{P} 321): 7-\mathrm{CeO}_{2}(\mathrm{Fm} 3 \mathrm{~m}) ; 8-\mathrm{Ag}^{0}$ 
Fig. 2 shows the SEM images of structures formed as part of lyophilized lanthanum and cerium-containing sediments. Whereas the hexagonal crystals of $\mathrm{La}(\mathrm{OH})_{3}$ belongs to $\mathrm{P}_{3} \mathrm{~m}$ space group (Fig. $2 a$ ) and the plate like $2 D$ crystals of $\mathrm{Ce}(\mathrm{OH})_{3}$ (Fig. 2 b) are formed in the presence of 4 wt. $\% \mathrm{AgNO}_{3}$, an addition of $\mathrm{Ce}\left(\mathrm{NO}_{3}\right)_{3}$ leads to change in the morphology of lanthanum hydroxide (Fig. 2 c). The average chemical composition of $\mathrm{La}(\mathrm{OH})_{3}$ according to
EDS-data includes wt. \%: 63 - La, 24 - O, and 13 total $\mathrm{N}, \mathrm{S}, \mathrm{K}$, but $\mathrm{Ag}$ is undetectable. The EDS spectrum of $\mathrm{Ce}(\mathrm{OH})_{3}$ shows, wt. \%: $66-$ $\mathrm{Ce}, 3.8-\mathrm{Ag}, 23-\mathrm{O}$, and $7.2-\mathrm{N}$. The composition of $\mathrm{La}(\mathrm{OH})_{3}$ formed in the presence of $\mathrm{Ce}^{3+}$ is as follows, wt. \%: $47-\mathrm{La}, 5-\mathrm{Ce}$, $35-\mathrm{O}$, and $13-$ total $\mathrm{N}$, Na. Therefore, the nature of rare earth species and doping elements determines the morphology and composition of primary phase.

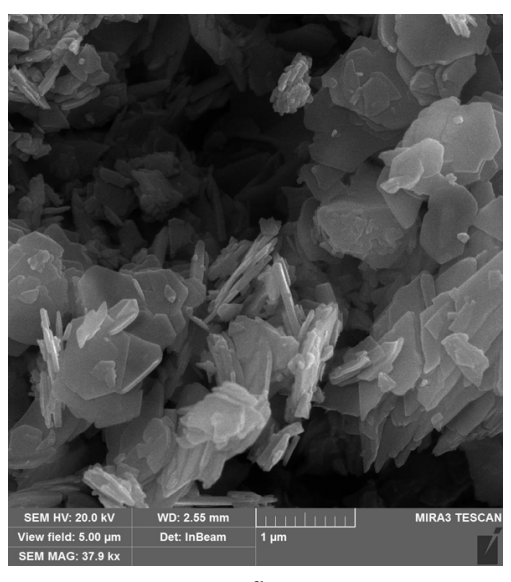

$a$
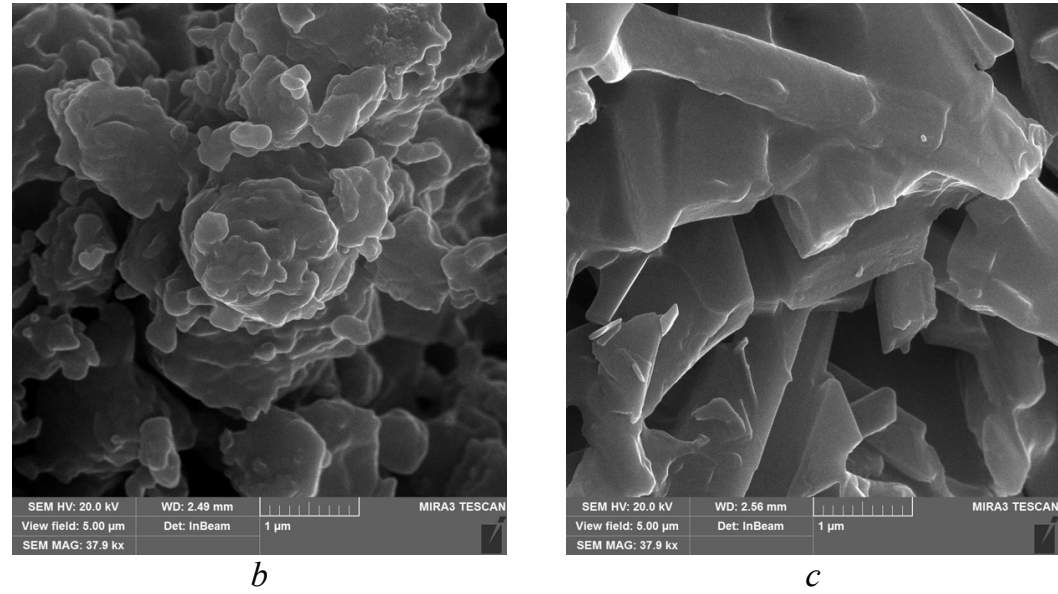

Fig. 2. SEM images of the precursor phases: $a-\mathrm{La}(\mathrm{OH})_{3}$ doped with $\mathrm{Ag}^{+} ; b-\mathrm{Ce}(\mathrm{OH})_{3}$ doped with $\mathrm{Ag}^{+} ; c-$ $\mathrm{La}(\mathrm{OH})_{3}$ formed in the presence of $\mathrm{Ce}^{3+}$

Fig. 3 shows the thermogravimetric analysis data of the initial samples obtained by co-precipitation of lanthanum and ceriumcontaining solutions with a solution of silver nitrate with silver concentration of $4 \mathrm{wt} \%$. There are two endothermic effects on the DTA curve of the lanthanum-containing sample (Fig. $3 a$ ), that indicate the completion of the $\mathrm{La}(\mathrm{OH})_{3}$ lattice dehydroxylation process at a temperature of $\sim 300{ }^{\circ} \mathrm{C}$ and probable destruction of sulfates at a temperature of $\sim 340^{\circ} \mathrm{C}$. The phase interaction of lanthanum oxide(III) with silver ends at $T \sim 400{ }^{\circ} \mathrm{C}$. The endothermic peak at $T=900{ }^{\circ} \mathrm{C}$ can be attributed to the change in the crystalline modification of lanthanum oxide. The DTG curve shows a twostage weight loss, which characterizes the destruction of lanthanum and silver hydroxides $\left(250^{\circ} \mathrm{C}\right)$ and the removal of sulfates $\left(\sim 340^{\circ} \mathrm{C}\right)$, respectively. Destruction of nitrate is observed at $T=380^{\circ} \mathrm{C}$. According to the $\mathrm{TG}$, the total weight loss is $21.6 \%$. Taking into account that during the preliminary preparation the samples were subjected to heat treatment at $T=160{ }^{\circ} \mathrm{C}$, there is no reflex on the DTG curve, which characterizes the loss of adsorption-bound water. For the cerium-containing system (Fig. $3 b$ ) the only endothermic effect is observed of dehydroxylation of cerium hydroxide at $T=250{ }^{\circ} \mathrm{C}$ with its conversion into cerium dioxide. The destruction of nitrates (anionic component of solutions) takes place at the temperature of $400{ }^{\circ} \mathrm{C}$. Weight loss takes place at $T=150{ }^{\circ} \mathrm{C}$ and is $53.9 \%$. Thus, on the basis of TG-DTA data, it can be assumed that the formation of composites particles based on lanthanum and cerium oxides, modified with silver, ends at the temperature of $400{ }^{\circ} \mathrm{C}$.

Characteristics of the products of phase transformation at $\boldsymbol{T}=400^{\circ} \mathrm{C}$. Heat treatment of lyophilized samples at the temperature of $400{ }^{\circ} \mathrm{C}$ leads to a change in their phase composition (Fig. 1 b). In particular, the lanthanumcontaining system has a dominant phase of $\mathrm{La}_{2} \mathrm{O}_{3}$ oxide (\# 05-0602). The diffraction pattern shows two weak reflexes of metallic silver (\# 4-0783). In the cerium-containing system (Fig. $1 d$ ), the formation of homogeneous 
nanosized particles of cerium dioxide (\# 34-0394) takes place. Dehydrated samples calcination at $400{ }^{\circ} \mathrm{C}$ for $5 \mathrm{~h}$ leads to the change in the particle morphology. In particular, hexagonal particles of lanthanum hydroxide are transformed into a trigonal (rhombohedral) structure of lanthanum oxide (silver clusters are restoring on its surface)

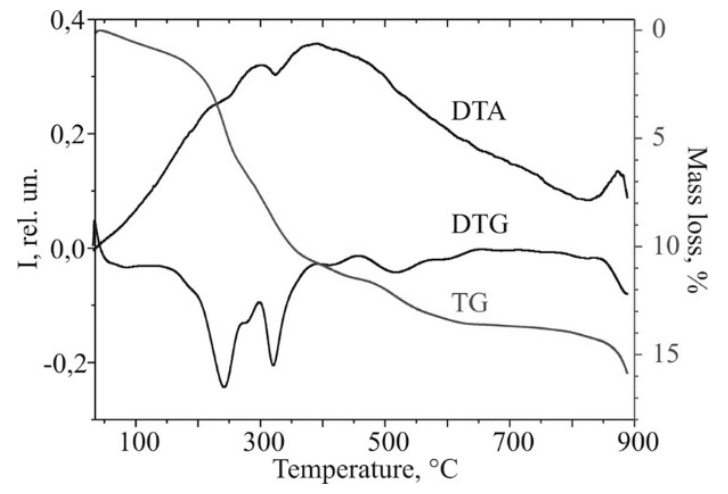

$a$
(Fig. $4 a$ ). The formation of cerium dioxide aggregates with evenly distributed small clusters of silver (Fig. $4 \mathrm{~b}$ ) is observed in the ceriumcontaining system. In the lanthanum-containing system, the presence of cerium (4 wt. \%) is seen in the nanosized $\mathrm{CeO}_{2}$ particles formed on the edges and planes of $\mathrm{La}_{2} \mathrm{O}_{3}$ plates (Fig. $4 c$ ).

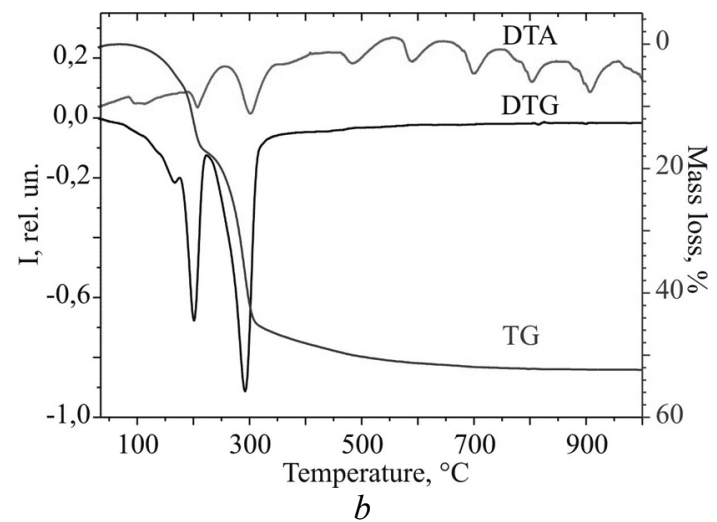

Fig. 3. TG-DTA curves of the primary samples formed via precipitation of RE salt solutions with $\mathrm{AgNO}_{3}$ in the light alkaline media in the systems: $a-\mathrm{La}_{2}\left(\mathrm{SO}_{4}\right)_{3}-\mathrm{Ag}^{+} ; b-\mathrm{Ce}\left(\mathrm{NO}_{3}\right)_{3}-\mathrm{Ag}^{+}$

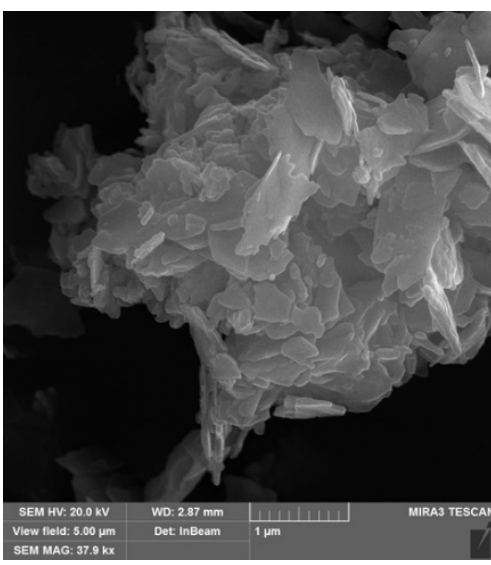

$a$

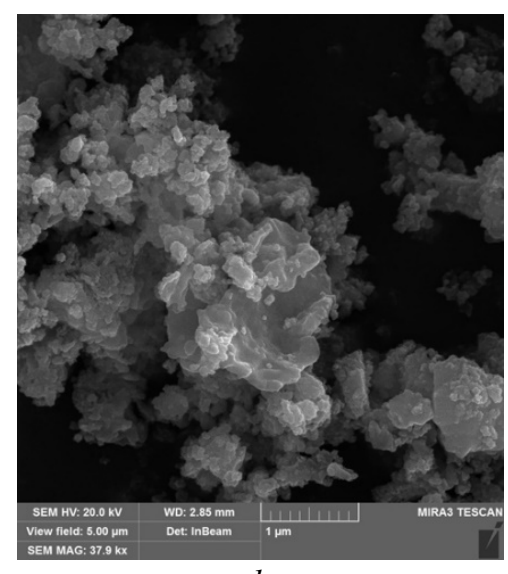

$b$

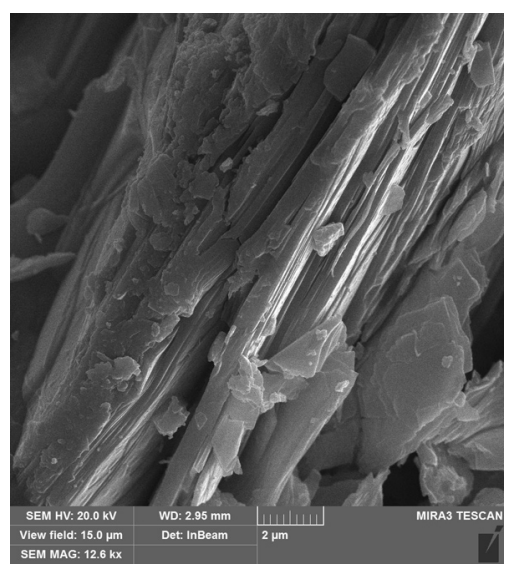

c

Fig. 4. SEM images of structures formed in systems at $T=400{ }^{\circ} \mathrm{C}: a$ - lanthanum sulfate - silver nitrate; $b$ - cerium nitrate- silver nitrate; $c$ - lanthanum sulfate - cerium nitrate

According to EDS spectroscopy, for the procedure of synthesis the use of lanthanum sulfate leads to the insertion of sulfur into the sample. For the system lanthanum sulphate silver nitrate $2 \mathrm{wt} . \%$, the average composition of the sample is: $\mathrm{O}-35, \mathrm{~S}-11.8, \mathrm{~K}-0.6, \mathrm{Ag}-$ $1.3, \mathrm{La}-51.3$. For the system cerium nitrate silver nitrate $4 \mathrm{wt} . \%$ the composition of the sample wt. \% is: $\mathrm{O}-13.6, \mathrm{Ag}-8.5, \mathrm{Ce}-77.9$. In the system of lanthanum nitrate - cerium nitrate with the content of the last $4 \mathrm{wt} . \%$ a precipitate is formed, the chemical composition of which contains wt. \%: $56-\mathrm{La} ; 3.4-\mathrm{Ce}$; $28-\mathrm{O} ; 3-\mathrm{Na} ; 9.6-\mathrm{N}$.

Characteristics of the products of red-ox process on oxide surfaces and next sintering of the samples at $T=400^{\circ} \mathrm{C}$. Particles of previously formed oxides lanthanum and cerium $\left(T=400{ }^{\circ} \mathrm{C}\right)$ were used to model the process of silver reduction from $\mathrm{AgNO}_{3}$ solution. A solution of hydroxyl amine chloride was chosen as the reducing agent. The obtained samples were subjected to additional heat treatment. According to X-ray diffraction, in the 
lanthanum-containing system there are phases of two oxides - trigonal $\mathrm{La}_{2} \mathrm{O}_{3}$ (\# 05-0602) and cubic $\mathrm{LaO}(\mathrm{F})$, and a phase of metallic silver (\# 6-0363) (Fig. 1 e). For the cerium-containing system, the phase of cerium dioxide (\# 34-0394) and metallic silver (Fig. $1 f$ ) was determined. According to EDS data, in the lanthanumcontaining system there are two types of structures that differ in their composition: the first type belongs to lanthanum oxides and in its chemical composition contains, wt. $\%-72-\mathrm{La}$; $10-\mathrm{Ag} ; 7.6-\mathrm{S} ; 10.4-\mathrm{O}$, and the second reduced silver, wt. \%: $96.6-\mathrm{Ag} ; 3.4-\mathrm{O}$. For a cerium-containing system is seen a uniform distribution of chemical elements in the composition of the sample, which is, wt. \%: $81-\mathrm{Ce} ; 3-\mathrm{Ag} ; 16-\mathrm{O}$. The SEM images show the morphology of rhombohedral lanthanum oxide particles (Fig. $5 a$ ) and spherical silver particles (clusters) on the surface of $\mathrm{La}_{2} \mathrm{O}_{3}$ plates (Fig. $5 \mathrm{~b}$ ). The morphology of the structures of the cerium-containing system is shown in (Fig. $5 c$ ). It is a spherical particle that forms aggregates and is localized on compacted aggregates of much larger size.

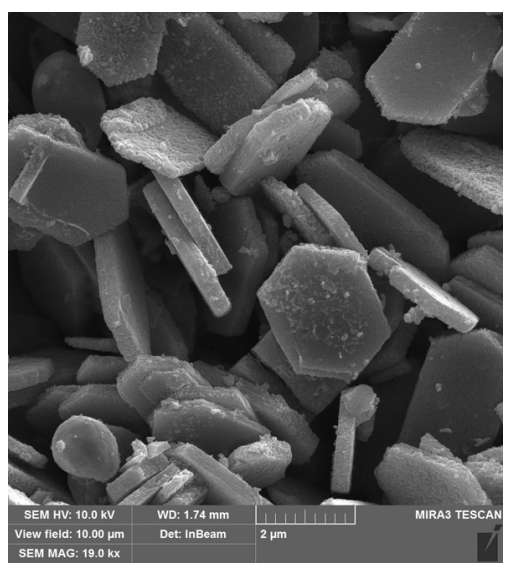

$a$

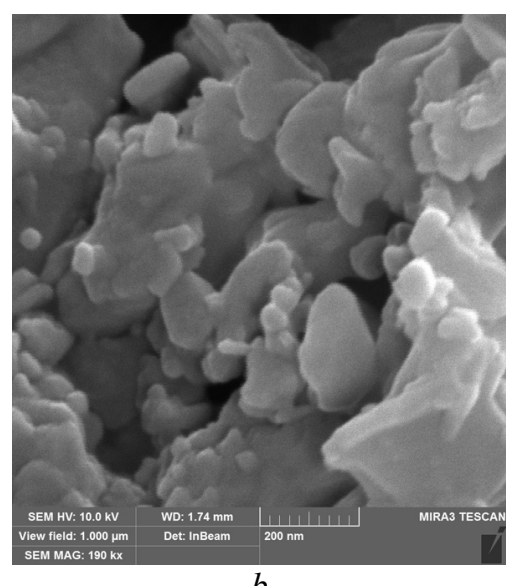

$b$

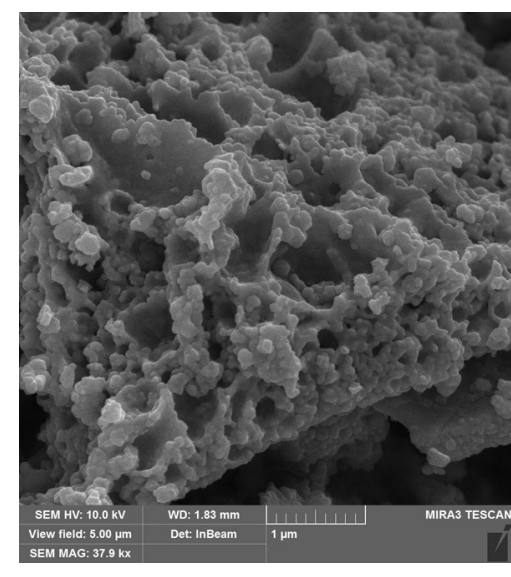

$c$

Fig. 5. Morphology of structures formed during the silver restoration from $\mathrm{AgNO}_{3}$ solution to the surface of oxide particles: $a$ - trigonal lanthanum oxide; $b$ - spherical particles (clusters) of silver on the surface of lanthanum oxide; $c$-spherical particles and aggregates of cerium dioxide with silver clusters on the surface

\section{Characteristics of phase formation products} in three-component $\mathrm{La}_{2} \mathrm{O}_{3}-\mathrm{CeO}_{2}-\mathrm{Ag}$ systems. Consideration of the phase composition of powders obtained in three-component systems based on lanthanum oxide, doped with cerium and silver, indicates that in systems with dopant' 2 and 4 wt. \% there are two lanthanum oxides belonging to the cubic syngony, spatial group la3 and trigonal syngony with the spatial group P3m1 (JCPDS file No. 02-0688), cerium dioxide with the spatial group Fm3m (JCPDS file No. 34-0394) and reduced silver (JCPDS file No. 04-0783). The difference is in the ordering (crystallinity degree) increasing for the sample with 4 wt. \% of dosing impurities (Fig. $1 h$ ), compared with the sample, which contains 2 wt. \% of cerium and silver (Fig. $1 g$ ).

At the same time, according to EDS data, the chemical composition of the samples contains, wt. \%: $62-\mathrm{La}$; $4-\mathrm{Ag} ; 10-\mathrm{O} ; 24-\mathrm{Cl}$, while the phase of cerium dioxide is not identified. The use of lanthanum chloride for the sample synthesis leads to the chlorine presence in the sediment composition.

The morphology of the structures formed in the lanthanum oxide system, modified with cerium and silver in the ratio of 2 and $4 \mathrm{wt} . \%$, is shown in Fig. 6. In Fig. $6 a$ the image is seen of deformed plates of lanthanum oxide, on the surface of which there are spherical nanometric particles of cerium dioxide and clusters of restored silver. In Fig. $6 b$ the enlarged image of such structures can be seen, and the difference in the sizes of the components of the three-phase dispersion is well observed. Clusters of silver on the lanthanum oxide surface are shown in Fig. $6 c$.

Thus, a study of morphology, phase and chemical composition of nano and microdimensional structures formed in the systems of inorganic salts of lanthanum, cerium nitrate and argentum, allowed us to determine the specifics 
of the phase formation process dependent on the chemical composition of the initial solutions, heat treatment of sediments and adding dopants, in particular, silver. Analysis of the ceriumcontaining system shows that at the initial stage of synthesis, which consists in the formation and lyophilization of the precipitate at $T=160{ }^{\circ} \mathrm{C}$, the composition of the precipitate is mainly cerium hydroxide(III). At the same time, the input of potential reducing agents into the suspension - the admixture of silver nitrate and sodium hydroxide, promotes the spontaneous course of the redox process - oxidation of $\mathrm{Ce}^{3+}$ to $\mathrm{Ce}^{4+}$, with the formation of $\mathrm{CeO}_{2}$ particles and nanoparticles or $\mathrm{Ag}^{0}$ clusters that was shown in [23].
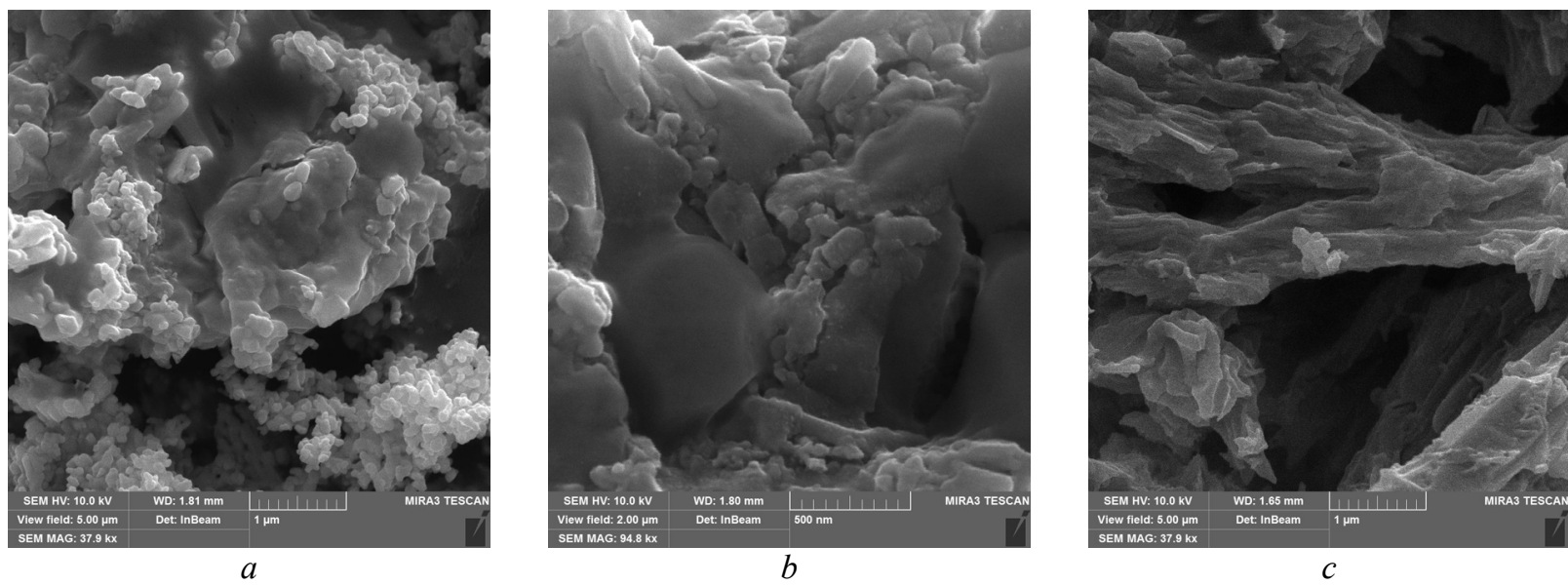

Fig. 6. Morphology of structures formed in the three-component $\mathrm{La}_{2} \mathrm{O}_{3}-\mathrm{CeO}_{2}-\mathrm{Ag}$ system: $a$ - the sample morphology general view; $b$ - deformed plates of lanthanum oxide with spherical nanoparticles of cerium dioxide; $c$ - clusters of silver on the surface of lanthanum oxide

Drying of the jelly-like precipitate at $T=160^{\circ} \mathrm{C}$ promotes the beginning of the $\mathrm{Ce}(\mathrm{OH})_{3}$ crystal lattice dehydroxylation with the formation of a slight impurity of the $\mathrm{Ce}_{2} \mathrm{O}_{3}$ phase. Subsequent heat treatment of the lyophilized sample leads to homogenization of the polyphase precipitate with the formation of spherical $\mathrm{CeO}_{2}$ particles, size $\sim 30 \mathrm{~nm}$, with evenly distributed on its surface clusters of silver. Silver restoration from $\mathrm{AgNO}_{3}$ solution in the presence of hydroxyl amine with subsequent calcination of the sample for $5 \mathrm{~h}$ at $T=400{ }^{\circ} \mathrm{C}$ leads to particle size increase of cerium dioxide and the appearance of a metallic silver reflex on the diffraction pattern. According to EDS, such a precipitate contains only such components as $\mathrm{Ce}$, Ag, O.

The lyophilized precipitate of the lanthanumcontaining system consists mostly of lanthanum(III) hydroxide structures, at the same time, the same as in the cerium-containing system, partial dehydroxylation of the $\mathrm{La}(\mathrm{OH})_{3}$ crystalline structure to the $\mathrm{La}_{2} \mathrm{O}_{3}$ formation and the presence of $\mathrm{LaO}$ impurity is observed. This is clearly seen by the reflexes on the diffraction pattern (Fig. $1 c$ ). In the initial samples of both systems, the presence of silver-containing compounds is not identified due to their low content ( 2 and 4 wt. \%) and the sensitivity limit of X-ray diffraction being equal to $5 \%$ by weight of the sample. Heat treatment of the sample $\left(400{ }^{\circ} \mathrm{C}\right)$ leads to its homogenization with formation of the dominant phase of $\mathrm{La}_{2} \mathrm{O}_{3}$ in trigonal syngony with spatial group $\mathrm{P} 3 \mathrm{~m} 1$. When a solution of silver nitrate and a reducing agent is inputted into the lanthanum oxide $\mathrm{La}_{2} \mathrm{O}_{3}$ (la3) system, a second phase of lanthanum oxide $\mathrm{LaO}(\mathrm{F})$ appears on the sediment, probably localized on the surface of trigonal $\mathrm{La}_{2} \mathrm{O}_{3}$ oxide particles, and silver clusters. In the chemical composition, according to the EDSF data, in the original sample, in addition to lanthanum and oxygen, impurities $\mathrm{N}, \mathrm{S}, \mathrm{K}$ are identified, but the presence of $\mathrm{Ag}$ is not detected. After the sample calcination at $T=400^{\circ} \mathrm{C}, \mathrm{La}, \mathrm{O}, \mathrm{Ag}$ and $\mathrm{S}$ remain in it. The same elemental composition is saved in the sample of lanthanum oxide with restored silver, but in this case the presence of lanthanum and silver-containing phases is clearly traced. 
The study of three-component systems in which the lanthanum-containing phase was supplemented by a cerium and silver in a mass dopants ratio 2 and 4 wt. \% indicates the presence of trigonal and cubic lanthanum oxides, a small content of cerium dioxide and metallic silver. The elemental composition is stable and contains wt. \%: $\mathrm{La}, \mathrm{Ce}, \mathrm{O}, \mathrm{Cl}$. The presence of chlorine is explained by the use of $\mathrm{LaCl}_{3}$ for sample synthesis. It is obvious that the anionic component of the dispersion medium is a part of the precipitate structure, so the choice of the anionic component of the salt is an important aspect in the further usage of such structures. In particular, chloride in contrast to sulfate and nitrate is the part of physiological solution $(0.9 \% \mathrm{NaCl})$ it seems promising to apply chloride solutions for the materials synthesis for medical and biological purposes.

\section{CONCLUSION}

The study of phase formation processes in the systems of inorganic cerium and lanthanum salts in the presence of silver nitrate and excipients - precipitators, nuclei and hydrolysis regulators shows that at the initial sludge drying stage the $\mathrm{Ce}(\mathrm{OH})_{3}$ or $\mathrm{La}(\mathrm{OH})_{3}$ phases dominate in its composition. Lyophilization of the precipitate at the temperature of $160{ }^{\circ} \mathrm{C}$ leads to partial dehydroxylation of the crystal lattice of hydroxides with the formation of $\mathrm{Ce}_{2} \mathrm{O}_{3}$ oxide or trigonal $\mathrm{La}_{2} \mathrm{O}_{3}$. At the same time, under the presence of silver and sodium hydroxide cations in the system, the $\mathrm{Ag}^{0}$ reduction and $\mathrm{Ce}^{3+}$ oxidation with the formation of the $\mathrm{CeO}_{2}$ phase are probable in the cerium-containing system. At the same time, the lanthanum-containing system is characterized by the formation of an additional phase of $\mathrm{LaO}$, it is most evident when one adds a reducing agent - hydroxyl amine chloride to the system. Calcination of the samples at $T=400{ }^{\circ} \mathrm{C}$ leads to homogenization of the precipitate composition - formation of $30 \mathrm{~nm}$ particles of cerium dioxide with evenly distributed on their surface clusters of silver, and lanthanum oxide with individual reduced silver nanoparticles. When silver is reduced on the surface of previously obtained oxides of cerium and cubic lanthanum, the particle size of $\mathrm{CeO}_{2}$ increases, and lanthanum is partially reduced to the $\mathrm{LaO}$ particles formation. The formation of two modifications of lanthanum oxides (cubic and trigonal), cerium dioxide and metallic silver is obvious for three-component systems based on lanthanum oxide doped with cerium and silver. From the morphology point of view, hexagonal plates of lanthanum hydroxide and oxide, spherical and close to the cubic shape of lanthanum oxide and cerium dioxide particles, as well as spherical clusters of silver are formed in the system. Talking about the chemical composition, in addition to the main chemical elements $\mathrm{Ce}, \mathrm{La}, \mathrm{O}, \mathrm{Ag}$, the systems have $\mathrm{S}$ or $\mathrm{Cl}$, dependent on the anionic component of the lanthanum salt, as well as $\mathrm{N}$ and $\mathrm{K}$.

\title{
Морфологія, фазовий і хімічний склад наноструктур, утворених в системах, які містять лантан, церій і срібло
}

\author{
О.М. Лавриненко, О.Ю. Павленко, М.М. Загорний, С.Ф. Корічев
}

Інститут проблем метеріалознавства ім. І.М. Францевича Національної академії наук України вул. Кржижановського, 3, Київ, 03680, Украӥна, alena.lavrynenko@gmail.com

\begin{abstract}
Методами рентгенофазового і термогравіметричного аналізу, скануючої електронної мікроскопї та енерго-дисперсійної спектроскопї проведено дослідження продуктів фазоутворення при осадженні солей лантану $і$ иерію в присутності нітрату срібла $i$ допоміжних речовин осадників, зародкоутворювачів $i$ регуляторів гідролізу. Термогравіметричний аналіз свідчить про те, щзо прочес дегідроксилювання кристалічної тратки La(OH) 3 закінчується за температури $\sim 300{ }^{\circ} \mathrm{C}$, а вірогідна деструкція сульфатів відбувається за температури $340{ }^{\circ} \mathrm{C}$. Фазова взаємодія оксиду лантану(III) з сріблом закінчується за $T \sim 400^{\circ} \mathrm{C}$. На кривій ДТГ спостерігається два рефлекси втрати маси, які характеризують руйнування структури гідроксидів лантану та срібла $\left(250^{\circ} \mathrm{C}\right)$ та видалення сульфатів $\left(\sim 340^{\circ} \mathrm{C}\right)$, відповідно. Згідно 3 даними ТГ, сумарна втрата маси становить 21.6\%. Для иерієвмісної системи простежується єдиний
\end{abstract}


ендотермічний ефект дегідроксилювання гідроксиду иерію за $T=250{ }^{\circ} \mathrm{C}$ та його перетворення на фазу діоксиду иерію. Руйнування нітратів (аніонна складова розчину) відбувається за температури $400^{\circ} \mathrm{C}$. Втрата маси простежується за $T=150{ }^{\circ} \mathrm{C}$ та становить $53.9 \%$. Таким чином, на підставі даних ТГ-ДТА встановлено, що утворення частинок композитів на основі оксидів лантану і иерію, модифікованих сріблом, закінчується за температури $400^{\circ} \mathrm{C}$. Згідно даних РФА, на вихідному етапі в системі триває формування гідроксидів изерію і лантану, а при ліофілізації осаду $\left(T=160^{\circ} \mathrm{C}\right)$ часткове дегідроксилювання кристалічної тратки гідроксидів з утворенням оксидів тригонального $\mathrm{La}_{2} \mathrm{O}_{3}$ i $\mathrm{Ce}_{2} \mathrm{O}_{3}$. Встановлено, щуо наявність в розчині катіонів срібла може впливати на фазовий склад ліофілізованих структур і сприяти утворенню фази СеО. Показано, щзо введення в систему хлориду гідроксиламіну може не тільки ініціювати відновлення срібла на поверхні оксиду лантану, але також частково відновлювати його до фази LaO. Температурна обробка зразків $\left(T=400^{\circ} \mathrm{C}\right)$ сприяє гомогенізачії складу осадів: формування 30 нм частинок діоксиду церію із рівномірно розподіленими на його поверхні кластерами срібла, та лусочока тригонального оксиду лантану 3 наночастинками срібла як другої фази. В трикомпонентних системах утворюються дві модифікації оксидів лантану (тригонального і кубічного), діоксид иерію і металічне срібло. Встановлено, що в осадах наявні головні елементи - La, Ce, O, $\mathrm{Ag}$ і домішні - S або $\mathrm{Cl}$, як аніонна складова вихідних розчинів. До складу вихідної суспензії входять також слідові кількості $N$ і К. Показано, щзо морфологія зразків представлена гексагональними структурами гідроксиду лантану $i$ тригональними - його оксиду, сферичними та псевдокубічними частинками діоксиду цеерію і оксиду лантану, сферичними кластерами срібла.

Ключові слова: тригональний оксид лантану, діоксид иерію, допування сріблом оксидів РЗЕ, фазоутворення, морфологія оксидів иерію і лантану, срібло

\section{REFERENCES}

1. Nethi S.K., Bollu V.S., Anand P.N.A., Patra C.R. Rare Earth-Based Nanoparticles: Biomedical Applications, Pharmacological and Toxicological Significance. In: Nanoparticles and their Biomedical Applications. (Singapore: Springer, 2020). P. 1-43.

2. Ivanov V.K., Shcherbakov A.B., Usatenko A.V. Structure-sensitive properties and biomedical applications of nanodispersed cerium dioxide. Russ. Chem. Rev. 2009. 78(9): 855.

3. Amoresi R.A.C., de Oliveira R.C., Marana N.L, de Almeida P.B., Prata P.S., Zaghete M.A., Longo E., Sambrano J.R., Simoes A.Z. $\mathrm{CeO}_{2}$ Nanoparticle Morphologies and their Corresponding Crystalline Planes for the Photocatalytic Degradation of Organic Pollutants. ACS Appl. Nano Mater. 2019. 2(10): 6513.

4. Younis A., Chu D., Li S. Cerium Oxide Nanostructures and their Applications. 2016. http://dx.doi.org/10.5772/65937.

5. Gil D., Rodriguez J., Ward B., Vertegel A., Ivanov V., Reukov V. Antioxidant Activity of SOD and Catalase Conjugated with Nanocrystalline Ceria. Bioengineering (Basel). 2017. 4(1): 18.

6. Baker Ch.H. Radiation Protection with Nanoparticles Chapter 14. In: Nanomedicine in Health and Disease. (Boca Raton: CRC Press, 2011). P. 268.

7. Celardo I., de Nicola M., Mandoli C., Pedersen J.Z., Traversa E., Ghibelli L. Ce 3 Ions Determine RedoxDependent Anti-apoptotic Effect of Cerium Oxide Nanoparticles. ACS Nano. 2011. 5(6): 4537.

8. Das M., Patil S., Bhargava N., Kang J.-F., Riedel L.M., Seal S., Hickman J.J. Auto-catalytic Ceria Nanoparticles Offer Neuroprotection to Adult Rat Spinal Cord Neurons. Biomaterials. 2007 28(10): 1918.

9. Asati A., Santra S., Kaittanis Ch., Nath S., Perez J.M. Oxidase-Like Activity of Polymer-Coated Cerium Oxide Nanoparticles. Angew. Chem. Int. Ed. Engl. 2009. 48(13): 2308.

10. Sicard C., Perullini M., Spedalieri C., Coradin Th., Brayner R.L.J., Jobbagy M., Bilmes S.A. CeO Nanoparticles for the Protection of Photosynthetic Organisms Immobilized in Silica Gels. Chem. Mater. 2011. 23(6): 1374.

11. Jing F.J., Huang N., Liu Y.W., Zhang W., Zhao X.B., Fu R.K., Wang J.B., Shao Z.Y., Chen J.Y., Leng Y.X., Liu X.Y., Chu P.K. Hemocompatibility and antibacterial properties of lanthanum oxide films synthesized by dual plasma deposition. J. Biomed. Mater. Res. Part A. 2008. 87(4): 1027.

12. Neacsu I.A., Stoica A.E., Vasile B.S., Andronescu E. Luminescent Hydroxyapatite Doped with Rare Earth Elements for Biomedical Applications. Nanomaterials. 2019. 9(2): 239.

13. Nilsson H., Dragomir A., Roomans G.M. Biomedical Applications of Lanthanum. (New York: Nova Biomedical Books, 2010).

14. Lee S.H., Jun B.H. Silver Nanoparticles: Synthesisand Application for Nanomedicine. Int. J. Mol. Sci. 2019. 20(4): 865. 
15. Gherasim O., Puiu R.A., Bîrcă A.C., Burdușel A.C., Grumezescu A.M. An Updated Review on Silver Nanoparticles in Biomedicine. Nanomaterials (Basel). 2020. 10(11): 2318.

16. Ullah Khan S., Saleh T.A., Wahab A., Khan M.HU., Khan D., UllahKhan W., Rahim A., Kamal S., UllahKhan F., Fahad S. Nanosilver: new ageless sand versatile biomedical therapeutic scaffold. Int. J. Nanomedicine. 2018. 13: 733.

17. Marin S., Vlasceanu G.M., Tiplea R.E., Bucur I.R., Lemnaru M., Marin M.M., Grumezescu A.M. Applications and toxicity of silver nanoparticles: a recent review. Curr. Top. Med. Chem. 2015. 15(16): 1596.

18. Liao C., Li Y., Tjong S.C. Bactericidal and Cytotoxic Properties of Silver Nanoparticles. Int. J. Mol. Sci. 2019. 20(2): 449.

19. Liu J., Zhang Li, Sun Y., Luo Y. Bifunctional Ag-Decorated $\mathrm{CeO}_{2}$ Nanorods Catalysts for Promoted Photodegradation of Methyl Orange and Photocatalytic Hydrogen Evolution. Nanomaterials. 2021. 11(5): 1104.

20. Wang K., Wu Y., Li H., Li M., Guan F., Fan H. A hybrid antioxidizing and antibacterial material based on Ag$\mathrm{La}_{2} \mathrm{O}_{3}$ nanocomposites. J. Inorg. Biochem. 2014. 141: 36.

21. Putri G.E, Arief S., Jamarun N., Gusti F.R, Sary A.N. Characterization of Enhanced Antibacterial Effects of Silver Loaded Cerium Oxide Catalyst. Orient J. Chem. 2018. 34(6): 2895.

22. Tsai D.-Sh., Yang T.-S., Huang Yu-Sh., Peng P.-W., Ou K.-L. Disinfection effects of undoped and silver-doped ceria powders of nanometer crystallite size. Int. J. Nanomed. 2016. 11: 2531.

23. Liu Y., Wang M., Cao L.-J., Yang M.-Y., Cheng S. H.-S., Cao Ch.-W., Leung K.-L., Chung Ch.-Y., Lu Zh.-G. Interfacial redox reaction-directed synthesis of silver@cerium oxide coreeshell nanocomposites as catalysts for rechargeable lithiumeair Batteries. J. Power Sources. 2015. 286 () 136e144.

24. Murugadoss G., Kumar D. D., Kumar M. R., Venkatesh N. \& Sakthivel P. Silver decorated $\mathrm{CeO}_{2}$ nanoparticles for rapid photocatalytic degradation of textile rose bengal dye. Sci. Rep. 2021. 11: 1080.

25. Samai B., Chall S., Mati S.S., Bhattacharya S.Ch. Role of Silver Nanocluster in Enhanced Photocatalytic Activity of Cerium Oxide Nanoparticle. Eur. J. Inorg. Chem. 2018. 2018(27): 3224.

26. Kayama T., Yamazaki K., Shinjoh H. Nanostructured ceria-silver synthesized in one-pot redox reaction catalyzes carbon oxidation. J. Am. Chem. Soc. 2010. 132(38): 13154.

27. Ferreira V.J., Tavares P., Figueiredo J.L., Faria J.L. Ce -Doped $\mathrm{La}_{2} \mathrm{O}_{3}$ based catalyst for the oxidative coupling of methane. Catal. Commun. 2013. 42: 50. 